УДК: $78.071 .2: 378$

DOI:

Юлія Харченко, концертмейстер кафедри теорії і методики музичної освіти та хореографії Мелітопольського державного педагогічного університету імені Богдана Хмельницького

\title{
ПРОФЕСІЙНА КУЛЬТУРА КОНЦЕРТМЕЙСТЕРА ЗАКЛАДУ ВИЩОЇ ОСВІТИ: ТЕОРЕТИКО-МЕТОДОЛОГІЧНИЙ АСПЕКТ
}

У статті проаналізовано окремі теоретичні та практичні питання професійної культури кониертмейстера закладу вищої освіти, визначаються підходи щодо актуальних проблем ії становлення у прочесі фахової діяльності. Досліджується зміст чотирьох-компонентної моделі професійної культури концертмейстера. Визначено сукупність иінностей, оволодіння якими створює підтрунтя для становлення професійної культури концертмейстера. Охарактеризовано чинники професійної культури концертмейстера закладу вищої освіти.

Ключові слова: культура; професійна культура конщертмейстера; професійна діяльність концертмейстера; компоненти професійної культури концертмейстера.

תim. 10.

Yuliya Harchenko, Concertmaster of the Theory and Methodology of Music Education and Choreography Department, Melitopol Bohdan Khmelnytskiy State Pedagogical University

\section{PROFESSIONAL CULTURE OF THE ACCOMPANIST IN THE HIGHER EDUCATION INSTITUTION: THEORETICAL-METHODOLOGICALASPECT}

The article analyzes some theoretical and practical issues of the formation of the professional culture of the accompanist in the higher education institution, caused by the necessity of adaptation to the changes taking place in the field of modern musical pedagogy. It is noted that a high level of professional culture allows the accompanist to search for effective approaches in his own practice. The necessity of interconnection of musical-performing preparation of the accompanist with general psychological, pedagogical and methodical preparation, which contributes to solving original creative problems, was emphasized. It is proved that the integral professional activity of the accompanist exists in the context of the relationship of axiological, technological, heuristic and personal components of professional culture. The content of the four-component model of professional culture of the accompanist is substantiated. The set of values is considered, the mastery of which creates the basis for the formation of professional culture of the accompanist: the musical and theoretical knowledge, general culture, personal qualities, self-education and self-development. The corresponding professional and personality-significant qualities are characterized, the presence of which ensures creative work of the accompanist: professional thinking, professional orientation, organizational qualities, communicative qualities. The basic ways of formation of the professional culture of the concertmaster are determined. It is concluded that the professional culture of the accompanist is a factor of the general pedagogical culture, the most important indicator of his professional skills and conformity to the international standards in the field of higher education.

Keywords: culture; professional culture of the accompanist; professional activity of the accompanist; components of the professional culture of the accompanist.

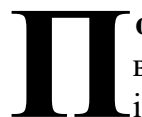

остановка проблеми. Зміни, які відбуваються в соціально-економічній i духовній сферах сучасного суспільства, тенденції, що намітилися у відновленні навчально-виховного процесу вирішальним чином впливають на стратегію і тактику розвитку вищої школи. Однією 3 найактуальніших проблем стає статус та професіоналізм фахівця, його прагнення до саморозвитку, бажання вирішувати істотні проблеми, готовність до інноваційної діяльності, що на сучасному етапі розвитку суспільства $\epsilon$ вкрай необхідним. Серед пріоритетів й напрямів модернізації системи освіти, затверджених у законодавчих документах (Концепція педагогічної освіти, Державна національна програма "Освіта" ("Україна XXI ст."), Державна програма “Вчитель”), відзначено найважливіше завдання: становлення фахівців нової формації, здатних до постійного професійного та культурного зростання. Євроінтеграційні процеси, які відбуваються в Україні ставлять перед фахівцями закладів вищої освіти нові виклики: оволодіння інноваційними технологіями та передовим досвідом у галузі педагогічної науки, здатність до системного мислення, наявність творчих та наукових здібностей, висока професійна компетентність. Для сучасної мистецької освіти є характерними 


\section{ПРОФЕСІЙНА КУЛЬТУРА КОНЦЕРТМЕЙСТЕРАЗАКЛАДУ ВИЩОЇ ОСВІТИ: ТЕОРЕТИКО-МЕТОДОЛОПЧНИЙ АСПЕКТ}

пошуки удосконалення музично-естетичної підготовки студентів. Саме тому професійна діяльність концертмейстера закладу вищої освіти передбачає наявність у фахівця грунтовних музично-теоретичних знань, широкого світогляду, значної психолого-педагогічної підготовки, здатностей до наукової та методичної роботи тощо. Сьогодні концертмейстер поставлений в ситуацію вибору і пріоритету індивідуального, творчого, інноваційного стилю професійної діяльності, що загострює проблему становлення його професійної культури. Вирішення цієї проблеми об'єктивно вимагає дослідження сутності та умов становлення професійної культури, аналізу теоретичних основ підвищення фахової компетентності концертмейстера, оскільки вдале поєднання професійно важливих та індивідуально-педагогічних якостей $\epsilon$ гарантією плідної практичної діяльності.

Аналіз основних досліджень і публікацій засвідчує, що одними з перших науковців, які розглядали становлення особистості викладача, були видатні педагоги А. Макаренко, В. Сухомлинський, К. Ушинський, котрі наголошували на тому, що висока освіченість у предметних знаннях, яка поєднана з педагогічною технікою, досвідом, моральними принципами є для нього найбільш значущими якостями. На творчому, дослідницькому підході педагогічної праці, зокрема на професійній творчості, наголошували I. Песталоцці, А. Дістервег.

Наукові праці останніх років свідчать про значні зміни в поглядах як на структуру професійної підготовки, так і на вимоги щодо особистості фахівця (А. Коломієць, О. Савченко, Л. Хомич [10], Л. Хоружа, І. Шапошнікова тощо). Теоретико-методологічним основам професійної діяльності фахівця присвячені дослідження В. Андрущенка, Б. Гершунського, Н. Глузман, В. Кременя, В. Лутая, В. Огнев'юка, Л. Хомич, Л. Хоружої, В. Шадрикова та ін. Значна кількість вітчизняних та зарубіжних науковців, а саме: А. Вербицький, А. Даринський, І. Дроздова, I. Галяміна, М. Єрмоленко, Н. Завіниченко, 3. Курлянд, В. Кучинський, В. Максимова, Г. Марченко, О. Мамчич, В. Міжериков, М. Нечаєв, А. Нікуліна, А. Проваров, А. Семенова, Ю. Татур, В. Ушаков, Г. Хмелюк, О. Шахматова, В. Шепель та ін. звертають увагу щодо проблеми розвитку професійної компетентності як інтегральної якості особистості викладача, яка сприяє найбільш ефективномуздійсненню практичної діяльності та саморозвитку.

Окремі питання професійної діяльності концертмейстера досліджували Г. Бошук,
Л. Годик, Н. Горошко, А. Григор'єв, Е. Економова, О. Кубанцева, Н. Лузум, Ю. Мірлас, М. Моісєєва, Д. Науказ, В. Пустовіт, В. Саранін, Г. Сибірякова, Г. Тенюкова, Є. Шендерович та ін. Так, М. Воротний наголошує, що становлення професійної культури концертмейстера полягає у подальшому розвитку його фахової майстерності, при цьому набуті раніше професійні якості поступово призводять до завершального етапу завдяки виникненню властивостей, які висуває професія. Науковець звертає увагу на багатогранну спрямованість діяльності концертмейстера в закладах вищої мистецької освіти. Схожуідею висловлює П. Євтихієв, котрий зазначає, що для розв'язання проблем та завдань, які має вирішувати концертмейстер з самого початку своєї роботи, необхідно мати великий обсяг не тільки предметних, але й психологопедагогічних знань, умінь та навичок, оскільки цілі музичного навчання мають комплексний характер.

Про важливі аспекти становлення особистості викладача йдеться у дослідженнях Г. Балла, С. Гончаренка, І. Зязюна, О. Пехоти, В. Семиченка, I. Беха, які стверджували на необхідності вдосконалення у процесі професійної діяльності таких моральних якостей, як: гуманність, духовна культура, рефлексія, емоційна стійкість, відповідальність тощо. На думку науковців, саме ці якості є чинниками особистісного зростання та важливою передумовою професійного становлення фахівця. Для сучасного наукового знання характерним є звернення до поняття “професійна культура викладача", до теоретикометодологічних засад та окремих аспектів яких звертали увагу В. Бенін, С. Бондаревська, О. Гармаш, В. Грехнєв, В. Гриньова, І. Ісаєв [4], Я. Коломинський, В. Лівенцова, Н. Ничкало, Я. Черньонков, І. Шевченко. Виявлення теоретичних основ дослідження культури, професійної культури як філософської категорії дозволяє наблизитися до розуміння феномену педагогічної культури. Як зазначає А. Барабанщиков, педагогічна культура - це “певна ступінь оволодіння викладачем педагогічним досвідом людства, ступінь його досконалості і педагогічної діяльності, досягнутий рівень розвитку його особистості" $[2,72]$. На основі дослідження особистісних якостей викладачів, аналізу наукових робіт А. Барабанщиков виокремлює основні складові педагогічної культури: педагогічна спрямованість особистості; психолого-педагогічна ерудиція i інтелігентність; моральна чистота; гармонія раціонального та емоційного; педагогічна 


\section{ПРОФЕСЙНА КУЛЬТУРА КОНЦЕРТМЕЙСТЕРАЗАКЛАДУ ВИЩОЇ ОСВІТИ:}

ТЕОРЕТИКО-МЕТОДОЛОГІЧНЙ АСПЕКТ

майстерність; вміння поєднувати педагогічну і наукову діяльність; система професійнопедагогічних якостей; педагогічне спілкування і поведінка; вимогливість; потреба в самовдосконаленні. Згаданий підхід робить перспективну заявку на розгляд професійної культури концертмейстера як складного системного новоутворення, компоненти якого окреслюють різні боки особистості фахівця, надана їхня педагогічна інтерпретація. Разом 3 тим ці свідчення професійної культури концертмейстера не може бути визнані завершеними, оскільки в них запропоновано декілька складових (виконавська майстерність і вміння поєднувати наукову й методичну діяльність, педагогічна спрямованість особистості та підвищена вимогливість до себе тощо); зафіксовано лише професійно-особистістні властивості, при цьому не відтворюється практична діяльність як найважливіший чинник професійної культури.

Існує ряд робіт, які розкривають окремі риси професійної культури: вивчаються питання методологічної (В. Сластьонін, В. Краєвський), морально-естетичної (Г. Ващенко, В. Петрушенко, С. Ціолковська), комунікативної (А. Мудрик), технологічної (М. Левіна), духовної (Н. Щуркова), фізичної (М. Віленський) культури особистості фахівця. У цих дослідженнях професійна культура розглядається як важлива частина загальної культури, невід'ємною складовою професійних якостей та своєрідністю діяльності викладача. I. Ісаєв вказує, що професійно-педагогічна культура об'єктивно існує не як можливість, а як реальна дійсність, яка дана лише тому, хто здатний до творчого переосмислення цінностей $\mathrm{i}$ технологій педагогічної діяльності та вносить власну частину в її подальший розвиток [4]. Проблемам становлення професійної культури приділяли увагу науковці С. Гончаренко, Л. Губерський, М. Євтух, В. Журавський, I. Зязюн, О. Савченко, О. Сердюк, І. Надольний, В. Огнев’юк, О. Абдуліна, Т. Іванова, Н. Кузьміна та ін. Однак на цей час, враховуючи інноваційні перетворення в освітньому просторі, проблема становлення професійної культури концертмейстера закладу вищої освіти 3 метою власного саморозвитку в інтелектуальній і професійній сфері вимагає більш ширшого теоретичного дослідження та практичного вирішення.

Мета статті полягає у визначенні наукових поглядів і думок щодо сутності і змісту професійної культури концертмейстера та розкриття актуальних проблем іiі становлення у процесі фахової діяльності у закладі вищої освіти.
Виклад основного матеріалу. Розвиток сучасного суспільства, входження України до європейської спільноти визначним чином передбачає готовність кожного фахівця, включаючи концертмейстера закладу вищої освіти до здійснення визначених державою завдань. Національна доктрина розвитку освіти України в XXI ст. передбачає суттєві зміни в підходах до вимог професійної діяльності викладача вищої школи - високо освіченої людини, творчої особистості, готової до інноваційної діяльності, орієнтованої на останні досягнення вітчизняної та зарубіжної науки і практики. Відтак, концертмейстер в умовах сьогодення покликаний до здійснення пошукунестандартних, ефективних підходів щодо вирішення професійних проблем, вміння генерувати оригінальні творчі ідеї, методи і прийоми організації навчальної діяльності студентів. Мова йде про професійні якості концертмейстера як цілісного суб' єкта: творчого, активного, здатного вміло поєднувати практичну діяльність та індивідуальну творчість. Отже, концертмейстер стає одним з носіїв культури у соціальне життя, йому належить значна роль у творенні духовного потенціалу країни, він у поєднанні з викладачем готує нову інтелектуальну еліту України, яка відзначається свободою мислення та певною критичністю поглядів, яка має мотивацію власної діяльності, особливу точку зору, демонструє гідну поведінку, спрямовану на досягнення мети, саморозвиток, змін відповідно до вимог життя. Такий підхід вимагає розв'язання проблеми становлення професійної культури концертмейстера, його здатності до навчання продовж життя, прагнення до саморозвитку, підвищення кваліфікації. Концертмейстер має володіти комплексом знань відповідного рівня і профілю, бути компетентним, відповідальним, здатним до ефективної роботи на рівні світових стандартів.

Професійна культура як особистісний i соціальний феномен незмінно перебуває у центрі уваги науковців. Зазвичай під поняттям “культура" розуміють певний рівень освіченості людини, ступінь іiі вихованості, а також здатність до оволодіння певною галуззю знань або діяльності. Професійна культура концертмейстера закладу вищої освіти насамперед передбачає наявність певного комплексу музично-теоретичних знань, виконавської компетентності, сформованості професійно значущих якостей, необхідних для успішної практичної діяльності [1]. Це поняття охоплює духовний, інтелектуальний, емоційний та практично-дієвий потенціал особистості концертмейстера та визначає не лише їі 
пізнавальні інтереси, а й обумовлює ціннісні орієнтації, світоглядні установки, життєве кредо загалом. Таким чином, професійна культура концертмейстера $є$ більш високим рівнем професіоналізму, який полягає у філософському осмисленні та саморефлексії професії і $€$ інтеграційною якістю особистості фахівця, умовою та передумовою іiї ефективної діяльності; складним новоутворенням, що інтегрує виконавську майстерність, професійну компетентність, здатність до науково-дослідної діяльності, рефлексивну культуру та яке спрямоване на професійний саморозвиток та самореалізацію $[6,14]$.

Досліджуючи соціокультурні чинники професійної діяльності, О. Рудницька розподіляє культуру на загальну і професійну. Науковець наголошує на необхідності оволодіння загальною культурою як невід'ємною ознакою професійної діяльності. О. Рудницька тлумачить професійну культуру як сукупність сформованих особистісних якостей фахівця, які відтворюються у кваліфікаційних уміннях і втілюються урізні види практичної діяльності. Саме особистісний розвиток має вплив щодо глибокого ціннісновмотивованого ставлення концертмейстера до посадових обов'язків та обумовлює адекватне осмислення процесів професійної діяльності $[8,7]$. На думку Б. Маркової, зрілість професійної культури зумовлена вузькопрофесійною й особистісною компетентністю, яка втілюється в усвідомленні соціальної відповідальності, самопрогнозуванні та саморефлексії $[7,65]$. Т. Іванова розглядає реалізацію професійної діяльності у поєднанні єдності цілей, засобів та результатів. Професійну культуру, на думку дослідниці, визначають: фахові знання, які втілюються у світогляд; здатність до творчого мислення; самоосвіта; саморозвиток; духовна культура; патріотизм; ерудованість; інтелігентність. Л. Хомич пов'язує професійну культуру фахівця із здатністю до вдосконалення власних можливостей щодо розв'язання своєрідних творчих проблем під час виконання професійних завдань [10].

Щоб мати чітке уявлення про сутність, структуру та зміст професійної культури, необхідно вдатися до моделювання досліджуваного феномена. Побудова моделі складних об'єктів існує за умов встановлення зв'язків між характеристиками будь-якого процесу. У побудові моделі професійної культури концертмейстера закладу вищої освіти ми виходили з таких методологічних передумов:

- професійна культура $є$ частиною загальної культури, і тому іï дослідження має спиратися на культурологічний підхід, який розкриває загальну структуру та механізм іï функціонування;

- професійна культура - це складне системне утворення, яке містить упорядковану сукупність загальнолюдських ідей, професійно-ціннісних орієнтацій і якостей фахівця, засобів технології професійної діяльності та має власну структуру (взаємозв'язок між компонентами);

- фахова діяльність концертмейстера розглядається в якості одиниці розгляду професійної культури та є одним з її елементів;

- особливості формування професійної культури концертмейстера закладу вищої освіти обумовлені індивідуально-творчими, психофізіологічними, віковими характеристиками, сформованим власним соціально-професійним досвідом.

Аналіз зазначених методологічних передумов надає можливості обгрунтувати чотирьохкомпонентну модель професійної культури концертмейстера.

1. Аксіологічний компонент, який розкриває професійну культуру концертмейстера у сукупності професійних цінностей, концепцій, створених людством впродовж тривалого часу. Перед фахівцями закладів вищої освіти постійно виникають завдання, які вимагають осмислення, оцінки педагогічної реальності, пошуку рішень у певних обставинах. Важливу роль при цьому відіграють активність, вибірковість особистості як в оцінці, так і при створенні тих чи інших цінностей. У процесі професійної діяльності концертмейстер опановує новими ідеями і концепціями, вдосконалює власні знання і вміння та, в залежності від ступеня їх важливості у практиці, оцінює іх як більш-менш значущі. Визначені явища, події, обставини, які насамперед становлять найбільшу значущість для суспільства, окремої педагогічної системи або власне самого концертмейстера, стають професійними цінностями фахівця [5]. Історія культури і педагогіки доводить, що цінності не залишаються незмінними у часі і просторі, вони переосмислюються відповідно до умов соціокультурного життя. На підставі цього, цінності концертмейстера можливо розглядати в якості своєрідних професійних прагнень, з якими фахівці співвідносять власну діяльність. Концертмейстер стає майстром своєї справи, професіоналом завдяки опануванню професійним досвідом, визнанню тих чи інших педагогічних цінностей. Отже, визначимо сукупність цінностей, оволодіння якими створює основу для становлення професійної культури концертмейстера. Перелік таких цінностей 


\section{ПРОФЕСИЙНА КУЛЬТУРА КОНЦЕРТМЕЙСТЕРА ЗАКЛАДУ ВИЩОЇ ОСВІТИ: ТЕОРЕТИКО-МЕТОДОЛОПЧЧИЙ АСПЕКТ}

виглядає наступним чином: музично-теоретичні знання й вміння; психолого-педагогічні знання; розвинене професійне мислення; високий рівень педагогічної рефлексії; педагогічний такт; усвідомлення необхідності у постійному саморозвитку й самоосвіті; творчий характер діяльності; неодмінність поєднання наукової та практичної діяльності; педагогічна етика; задоволеність працею; культура мови та ін. Таким чином, концертмейстер закладу вищої освіти виокремлює цінності, що розкривають насамперед творчий характер власної професійної діяльності. Визнаючи важливість аксіологічного компоненту професійної культури фахівця, необхідно доповнити іiі іншими складовими.

2. Технологічний компонент професійної культури як своєрідний модус концертмейстерської діяльності. Таке розуміння професійної культури підходить філософському поясненню культури, що надають В. Давидович, Ю. Жданов, Е. Маркарян, О. Ханова i iн. Авторами відстоюється необхідність дослідження культури як складного, суперечливого явища, відправною тезою якого $€$ спосіб діяльності. Розгляд цього поняття змушує звернутися до проблеми співвідношення понять “професійна культура" і “професійна діяльність". Їх взаємозв’ язок безсумнівний, оскільки розвиток і вдосконалення практичної діяльності сприяє накопиченню цінностей і підвищенню професійної культури, саме в процесі діяльності створюються і закріплюються уявлення, технології, зразки професійної культури. У свою чергу, професійна культура як узагальнена характеристика діяльності визначає розвиток найбільш пріоритетних, перспективних і необхідних напрямків практичної діяльності. Технологічний компонент професійної культури концертмейстера розкриває шляхи здійснення практичної діяльності, засоби отримання нової інформації, передавання накопиченого досвіду, тобто усього того, що створює основу професійної культури. Зміст концертмейстерської технології складають: інструментально-виконавська техніка; технологія опанування інструментальним супроводом твору; технологія роботи з вокалістами, диригентами, хореографами, інструменталістами; технологія розучування вокальних, хорових партій із студентами; технологія контролю за якістю звучання музичного твору; технологія “читання 3 аркуша" музичного твору; технологія ансамблевої гри; технологія транспонування нотного тексту у зручну тональність; технологія підбору мелодії; технологія гри в ансамблі; технологія осягнення алгоритмів вирішення професійних завдань; технологія спілкування із студентом-солістом та викладачем, технологія допомоги в організації самостійної, індивідуальної роботи студентів, технологія педагогічної вимоги, технологія вирішення конфліктів і ін. Можна істотно продовжити перерахування цих технологій, оскільки концертмейстерська діяльність $є$ технологічною за своєю сутністю. Відображення технологічного компонента через систему стандартних психолого-педагогічних завдань дозволяє визначити проблему формування методів і прийомів оптимальної професійної діяльності концертмейстера. Логіка рішення психолого-педагогічних завдань складається 3 ряду послідовно пов'язаних етапів: педагогічного аналізу ситуації; визначення мети й планування; конструювання та реалізації творчого процесу; регулювання і коригування; обліку та оцінки отриманих результатів. Згадані етапи є досить відносними, але вони сприяють розумінню динаміки позначених процесів в їх складностях й суперечливостях.

3. Евристичний компонент професійної культури як прояв педагогічної творчості. Цінності професійної діяльності, технологія їх втілення у навчально-виховний процес стають чинниками становлення особистості фахівця лише в умовах творчої діяльності. Для концертмейстера, який бажає опанувати професійною культурою, стати майстром своєї справи, необхідно перш за все усвідомити власну діяльність як творчість. Дослідження психології творчості, виконавської творчості, педагогічної творчості створюють передумови для розуміння і осмислення творчої природи діяльності концертмейстера. Визнання творчості як важливої складової професійної культури музиканта загалом, призводить до необхідності визначення етапів творчої діяльності концертмейстера. Можливо визначити наступні етапи у творчості концертмейстера: виникнення співтворчого задуму із викладачем та студентом, спрямованого на вирішення творчого завдання; розробка творчого задуму; втілення задуму у спільній музично-виконавській діяльності; аналіз і оцінка результатів творчості [3]. Творче рішення професійних завдань в кожному окремому випадку залежить від врахування концертмейстером специфіки власної діяльності, іiї суперечливості, діалектичності, особливості її суб'єкта і об'єкта. Відтворення професійної культури визначається тим, як він здійснює зміни від одного етапу до іншого, чи враховує при цьому відрізок часу і завершеність кожного етапу. Прояв творчого компонента професійної культури концертмейстера залежить і від готовності учасників (викладач концертмейстер - студент) до творчої діяльності, 


\section{ПРОФЕСІЙНА КУЛЬТУРА КОНЦЕРТМЕЙСТЕРАЗАКЛАДУ ВИЩОЇ ОСВІТИ: ТЕОРЕТИКО-МЕТОДОЛОПЧНИЙ АСПЕКТ}

оскільки творче ставлення до різних видів діяльності, безумовно, стимулює творчу активність фахівця. Висловлене дозволяє зробити висновок про професійну творчість як іманентну характеристику професійної культури, спрямовану на становлення творчої індивідуальності студента і концертмейстера.

4. Особистісний компонент розкриває професійну культуру концертмейстера закладу вищої освіти як специфічний спосіб реалізації його внутрішніх сил, а саме: потреб, здібностей, інтересів, соціального досвіду, рівня соціальної активності. Професійна діяльність створює концертмейстерові певні умови щодо творчої самореалізації, позитивна спрямованість якої визначається не тільки зовнішнім впливом, але й внутрішніми запитами фахівця. Потреба в самореалізації є джерелом особистісно-смислової активності людини, спрямованої на постійний саморозвиток, самовиховання [9]. Функціонування професійної культури концертмейстера $є$ постійним перетворенням особистого досвіду в колективні форми професійної культури, а цих загальних форм - знов у власне професійне “Я”. У зв'язку з цим виникає важливе питання про механізми самореалізації, іiі етапи. Самореалізація як самостійна діяльність особистості визначається характером мети та ступеню їі особистого розуміння й прийняття. Усвідомлення цілей власної професійної діяльності, активно-позитивне, емоційно-ціннісне ставлення до неї сприяють актуалізації особистісних професійнопедагогічних якостей концертмейстера, створюють умови для постійного самопізнання. Самопізнання і самооцінка знаходяться в діалектичній єдності із самореалізацією. У процесі професійної діяльності концертмейстера відбувається подальше самопізнання та створюється емоційне ставлення до себе; що стає умовою організації фахової діяльності, спонуканням до здійснення особистісносмислової активності, основою якої стає прагнення щодореалізації власних можливостей (інтелектуальних, духовних, творчих, комунікативних). Особистіснопрофесійна самореалізація власних творчих можливостей становить, на наш погляд, сутність професійної культури концертмейстера закладу вищої освіти. У процесі самореалізації концертмейстер зважує власні професійносоціальні потреби, здібності, обдарування, творчі можливості в професійній і наукової діяльності. Джерелом самореалізації з'являються протиріччя між особистісною, професійною метою і реальним наближенням до них. Діалектичність цього процесу полягає в тому, що концертмейстер, передаючи свій досвід, знання, моральні якості, реалізуючи свої здібності в науково-педагогічної діяльності, набуває іншого, більш високого професійного потенціалу, стає носієм професійної культури. Різноманіття видів самореалізації визначається різноманіттям видів діяльності концертмейстера: навчальної, виховної, методичної, дослідницької, суспільно-педагогічної.

Аналіз різних досліджень щодо визначення сутності та змісту професійної культури пересвідчує про те, що сучасна педагогічна наука філософськи осмислено тлумачить це поняття не лише як наслідок вузькопрофесійної підготовки фахівця, але як цілісне виявлення його світогляду й розвитку всіх соціально значущих особистісних якостей, як інтегрального показника творчої спрямованості, духовності та активного ставлення до життя. Отже, можливо виокремити наступні риси професійної культури концертмейстера:

- система музично-теоретичних знань, умінь та навичок;

- здатність до творчої співпраціпраці;

- загальна культура (світоглядна, духовна, чуттєвоемоційна);

- професійно значущі складові особистісної культури (розумова, комунікативна, мовленнєва, дослідницька, фізична);

- активна життєва позиція, потреби у самоосвіті та саморозвитку.

Загальновідомо, що професійна культура невід’ємна складова професійної діяльності. Задля того щоб концертмейстер став майстром своєї справи, він має бути особистістю з високим рівнем загальної культури, етичності та людяності, професійної індивідуальності й винятковості, власного стилю, розвинутого мислення. Все це свідчить про необхідність оволодінням концертмейстером у професійній діяльності ключовими компетентностями, тобто поєднаннями музично-теоретичних та психолого-педагогічних знань 3 умінням застосовувати ці знання, враховуючи новітні освітні стандарти [1]. Найважливішими серед них $є$ : виконавська компетентність, яка відзначається досконалим володінням технікою гри на музичному інструменті; знання психології та етики спілкування; здатність до співпраці; уміння аналізувати проблеми, розробляти план дій, здатність до їх реалізації та відповідальності за виконання; свідоме, усталене, позитивне ставлення до професії; прагнення до постійного особистісного професійного саморозвитку й самореалізації; застосування різноманітних творчих засобів на практиці, вміння користуватися сучасними інформаційними технологіями; комунікативна готовність тощо. 


\section{ПРОФЕСІЙНА КУЛЬТУРАКОНЦЕРТМЕЙСТЕРАЗАКЛАДУ ВИЩОЇ ОСВІТИ:}

ТЕОРЕТИКО-МЕТОДОЛОПЧНИЙ АСПЕКТ

Такий погляд на професійну культуру концертмейстера зумовлює існування у нього відповідних професійних і особистісно-значущих якостей, серед яких:

- професійне мислення складовими якого $€$ такі якості: аналітико-конструктивізм, динамічність, креативність, самостійність, критичність, спостережливість тощо;

- професійна спрямованість, яка детермінована ефективністю реалізації репетиційного та концертно-виконавського процесу. До її складників належать: інтерес до професійної діяльності, високий рівень професійної майстерності, усвідомленість професійних дій, здатність працювати за різними напрямками (із вокалістами, хоровими диригентами, хореографічними колективами, інструменталістами), уміння і навички рефлексії, адекватна самооцінка, принциповість, гуманістична спрямованість, сформованість духовних цінностей, позитивне ставлення до учасників навчального процесу;

- організаційні якості: відповідальність, працездатність, самостійність, ініціативність,вимогливість, наполегливість, прагненнящодопрофесійноїсаморегуляції(самоконтролю, самокорекціі) тощо;

- комунікативні якості, які сприяють успішній реалізації усіх видів професійно-творчої діяльності. Серед них: емпатійність, толерантність, витримка, самоконтроль, емоційно-вольова стійкість, відчуття такту, позитивна стабільність тощо.

Наявність вищезгаданих якостей забезпечують плідну роботу концертмейстера, оскільки сприяють його професійному становленню, зумовлюють стиль і творчий характер діяльності та значно підвищують результат праці. Оскільки концертмейстер має бути фахівцемпрофесіоналом з високою загальною культурою, розвиненими творчими та науковими здібностями, високим рівнем інтелектуального потенціалу, уміннями доносити власну точку зору та узагальнювати результати своєї праці, наявністю свого іміджу, манери спілкування тощо, необхідно визначити професійні вимоги до його діяльності:

- усвідомлення призначення музичного мистецтва у різних видах художньо-виконавської діяльності;

- розуміння специфіки акомпанементу;

- розуміння методик викладання різних дисциплін: вокальних, диригентсько-хорових, хореографічних, інструментальних;

- володіння значним репертуаром: вокальним, диригентсько-хоровим, хореографічним, інструментальним;

- вміння опановувати програму у найшвидший час, акомпанувати з аркуша;
- вміння працювати 3 викладачем, а за його відсутністю брати на себе частину його функцій;

- прагнення до створення плідної творчої атмосфери у співпраці з викладачем і студентом;

- сприяння розвитку музичних уявлень студентів, вихованню їх художнього смаку;

- підвищення упродовж життя свого професійного рівня;

- опанування новими знаннями та здатність до використання їх на практиці;

- готовність до творчого саморозвитку та самореалізації;

- вміння здійснювати самоконтроль над негативними емоціями та думками.

Висновки. Підсумовуючи викладене, відзначимо, що професійна культура концертмейстера є чинником загальної педагогічної культури, найважливішим показником його професійної майстерності і відповідності світовим стандартам у галузі вищої освіти. Задля того, щоб в умовах сучасної музичної освіти концертмейстер мав здатність виконувати професійну діяльність на високому рівні, вмів викликати в студентів бажання до навчання, він зобов'язаний мати високий рівень професійної культури. Таким чином, покращення теоретичних уявлень щодо професійної культури концертмейстера має велике значення для вдосконалення його професійної діяльності через магістратуру, аспірантуру, систему підвищення кваліфікації. Особливу перспективність і практичне значення таке дослідження має в даний час у зв'язку зі значним припливом молодих фахівців. Концертмейстер закладу вищої освіти потребує постійного збагачення музичнотеоретичних та психолого-педагогічних знань, вдосконалення виконавської майстерності і розуміння методик викладання окремих дисциплін (вокально-хорових, хореографічних, інструментальних). Спрямованість на індивідуально-творчі, діалогічні форми роботи у закладах вищої освіти вимагає від концертмейстера переоцінки сформованих підходів щодо власної діяльності та стилю професійного мислення.

\section{ЛІТЕРАТУРА}

1. Балашова О. С. Концертмейстерька компетентність - неодмінна умова професійного становлення вчителя музики. Підготовка вчителя у контексті Європейського освітнього простору: Збірник наукових праць / за ред. проф. М. В. Левківського. Київ-Житомир, 2005. С. 113-120.

2. Барабанщиков А. В.Проблемы педагогической культуры преподавателей вузов. Сов. педагогика. 1981. № 7.

3. Душний А. Методика активізації творчої 


\section{ПРОФЕСІЙНА КУЛЬТУРА КОНЦЕРТМЕЙСТЕРАЗАКЛАДУ ВИЩОЇОСВІТИ: ТЕОРЕТИКО-МЕТОДОЛОПЧЧИЙ АСПЕКТ}

діяльності майбутніх учителів музики у процесі музично-інструментальної підготовки : навч.метод.пос. для студ. вищих навч. закл. Дрогобич, $2008.120 \mathrm{c}$.

4. Исаев И. Ф. Профессионально-педагогическая культура преподавателя. Москва, 2004. 208 с.

5. Луговий В. І. Формування ціннісної компетентності науково-педагогічних працівників - важлива умова їх успішної діяльності в сучасній вищій школі. Проблеми освіти : наук. зб. Ін-т іннов. технологій змісту освіти МОН України. Київ, 2010. Вип. 63, Ч. 1. С. 3-9.

6. Мазур Н. Зміст професійної культури викладача вищої школи. Рідна школа. 2007. № 4. C. $12-14$.

7. Маркова Б. С. Психологические проблемы повышения квалификации. Педагогика. 1993. №9-10. С. 64-67.

8. Рудницька О. П. Сприйняття музики і педагогічної культури вчителя. Київ, 1992. 96 с.

9. Сегеда Н. А. Інституціоналізація професійного розвитку викладача музичного мистецтва у вітчизняній системі безперервної педагогічної освіти. Педагогічна освіта: теорія і практика. 2011. Вип. 8. С. 352-358.

10. Хомич Л. Роль мистецтва у професійнопедагогічній підготовці вчителя. Мистецтво та освіта. 1998. № 3. С. 51-54.

\section{REFERENCES}

1. Balashova, O. S.(2005). Kontsertmeisterka kompetentnist - neodminna umova profesiinoho stanovlennia vchytelia muzyky [Accompanist's competence - an indispensable condition for the professional formation of a music teacher]. Teacher training in the context of the European educational space: Collection of scientific works, edited by M. V. Levkovsky. Kyiv-Zhytomyr, pp. 113120. [in Ukrainian].

2. Barabanshchykov, A. V. (1981). Problemy pedahohycheskoi kultury prepodavatelei vuzov [Problems of pedagogical culture of university lecturers]. Soviet pedagogy. 7. [in Russian].

3. Dushnyi, A. (2008). Metodyka aktyvizatsii tvorchoi diialnosti maibutnikh uchyteliv muzyky u protsesi muzychno-instrumentalnoi pidhotovky [Method of activating the creative activity of future music teachers in the process of musical and instrumental training]. Educational and methodical manual. Drohobych, 120 p. [in Ukrainian].

4. Ysaev, Y. F. (2004). Professyonalnopedahohycheskaia kultura prepodavatelia [Professional and pedagogical culture of a teacher]. Moscow, 208 p. [in Russian].

5. Luhovyi, V. I. (2010). Formuvannia tsinnisnoi kompetentnosti naukovo-pedahohichnykh pratsivnykiv - vazhlyva umova yikh uspishnoi diialnosti v suchasnii vyshchii shkoli [Formation of the value competence of scientific and pedagogical workers - an important condition for their successful activity in the modern high school]. Institute of innovative technologies of the content of education Ministry of Education of Ukraine. Kiyv, 63 (1), pp. 3-9. [in Ukrainian].

6. Mazur, N. (2007). Zmist profesiinoi kultury vykladacha vyshchoi shkoly [Content of the professional culture of a higher school lecturer]. Native School, 4, pp. 12-14. [in Ukrainian].

7. Markova, B. S. (1993). Psykholohycheskye problemы povyshenyia kvalyfykatsyy [Psychological problems of professional development]. Pedagogy, 9-10, pp. 64-67. [in Russian].

8. Rudnytska, O. P. (1992). Spryiniattia muzyky i pedahohichnoi kultury vchytelia [Perception of music and pedagogical culture of the teacher]. Kyiv, 96 p. [in Ukrainian].

9. Segeda, N. A. (2011). Instytutsionalizatsiia profesiinoho rozvytku vykladacha muzychnoho mystetstva u vitchyznianii systemi bezperervnoi pedahohichnoi osvity [Institutionalization of professional development of the teacher of musical art in the domestic system of continuous pedagogical education]. Pedagogical education: theory and practice, 8, pp. 352-358. [in Ukrainian].

10. Khomych, L. (1998). Rol mystetstva u profesiino-pedahohichnii pidhotovtsi vchytelia [The role of art in vocational and pedagogical teacher training]. Art and Education, 3, pp. 51-54. [in Ukrainian].

Стаття надійшла до редакції 06.03.2019

\section{G5808010\%}

"Таємниия успіху в житті полягає в тому, щоб бути готовим скористатись is слушної нагоди, қоли вона настане". 